\begin{tabular}{|l|l|l||}
\hline \multicolumn{2}{|c|}{ PublisherInfo } \\
\hline \hline PublisherName & $:$ & BioMed Central \\
\hline \hline PublisherLocation & $:$ & London \\
\hline \hline PublisherImprintName & $:$ & BioMed Central \\
\hline \hline
\end{tabular}

\title{
ARF in the elderly
}

\begin{tabular}{|l|l|l||}
\hline \multicolumn{2}{|c|}{ ArticleInfo } \\
\hline \hline ArticleID & $:$ & 4203 \\
\hline \hline ArticleDOI & $:$ & $10.1186 /$ ccf-2000-5360 \\
\hline \hline ArticleCitationID & $:$ & 5360 \\
\hline \hline ArticleSequenceNumber & $:$ & 62 \\
\hline \hline ArticleCategory & $:$ & Paper Report \\
\hline ArticleFirstPage & $:$ & 1 \\
\hline \hline ArticleLastPage & $:$ & 3 \\
\hline \hline & & RegistrationDate : 2000-5-31 \\
\hline ArticleHistory & $:$ & OnlineDate \\
\hline \hline ArticleCopyright & $:$ & Current Science Ltd2000-5-31 \\
\hline \hline ArticleGrants & $:$ & \\
\hline \hline ArticleContext & $:$ & 1305422 \\
\hline \hline
\end{tabular}


Aff1 St Georges' Hospital, UK

\section{Keywords}

\section{Comments}

Patients over 80 years old constitute an increasing number of acute renal failure (ARF) admissions to the ICU. ICU mortality is high, although from this historical cohort study, it appears to be no greater than the overall mortality for ARF in the ICU. However, less than one third of patients required haemodialysis and those that did, had a worse prognosis, although a mortality figure is not quoted in the paper. Consequently, the most important question, whether it is in the elderly patient's best interests to offer some form of dialysis therapy on the ICU, remains unanswered. Very few intensivists would deny fluid resuscitation, invasive haemodynamic monitoring and pharmacological support for any age group with ARF, who was pre-morbidly physiologically well, with a good quality of life. This would appear to have been the primary therapy for two thirds of patients admitted with ARF in this study, since they did not receive dialysis. Prognosis following ICU discharge is not available from this study due to insufficient follow-up data.

\section{Introduction}

The economics of health care are carrying increasing importance when decisions on the admission of patients to the ICU are made. The elderly feature prominently in this debate and this paper reviews the prognosis for patients over 80 years old admitted with to the ICU with ARF.

\section{Methods}

- Historical cohort analysis of 381 patients over 80 years old admitted to a French renal ICU between 1971 and 1996. 
- $\mathrm{ARF}$ defined as creatinine $>120 \mu \mathrm{mol} / \mathrm{l}$. If pre-existing renal disease, ARF defined as creatinine increase of $>50 \%$ from basal level.

- ICU mortality and mortality after hospital discharge were measured.

\section{Results}

The proportion of patients over 80 years old admitted with ARF rose from 4\% pre 1978 to a current rate of $40 \%$. Two thirds of patients had no previous history of renal disease. Patients were admitted from home (49\%), a medical unit (37\%), or surgery (12\%). The aetiology of ARF was obstructive (22\%), prerenal (24\%- predominantly dehydration), and intrinsic renal disease (54\%- predominantly cardiogenic, septic or hypovolaemic shock). A nephrotoxic drug was involved in $18 \%$ of patients. Haemodialysis was required in $29 \%$ of patients. ICU mortality was $40 \%$, with the majority (69\%) having intrinsic renal failure. Haemodialysis was an independent risk factor associated with a poor prognosis in the intrinsic renal failure group. Following ICU discharge, 20\% of patients died during the first 12 months although data is only available for less than $50 \%$ of patients. It appears that only about $50 \%$ of patients surviving the ICU were alive at 2 years.

\section{References}

1. Akposso K, Hertig A, Couprie R, Flahaut A, Alberti C, Karras GA, Haymann JP, Costa De Beauregard MA, Lahlou A, Rondeau E, Sraer JD: Acute renal failure in patients over 80 years old: 25-years' experience. Intensive Care Med. 2000, 26: 400-406.

This PDF file was created after publication. 